\author{
Rustam Haidov \\ Near East University, Cyprus \\ Hanife Bensen \\ Near East University, Cyprus
}

\title{
FLIPPED LEARNING IN EDUCATION: A CONTENT ANALYSIS
}

\begin{abstract}
Summary. The continuously progressive education system of the $21^{\text {st }}$ century requires the introduction of innovative teaching methodologies incorporating up-to-the-minute technology-oriented styles, which are capable of changing the traditional ways of conducting classes presenting teachers as the ultimate source of knowledge, with a new notion which considers teachers as facilitators and guiders in the world of information. A plethora of research has been conducted with respect to flipped learning, however, the number of research papers presenting content analysis is limited indicating the deficiency and lack of content analysis-based papers on Flipped Classroom in Education. Thus, to fill this gap in the literature, there is a demand for conducting a content analysis. In turn, the aim of this paper was to identify the importance and impact of the distributed documents on a Flipped Learning Model (FLM) in Education which was done by gathering data from the SCOPUS database with keywords 'Flipped Classroom in Education', within the range of ten years (2011-2020). All studies published in SCOPUS, were statistically analyzed and examined according to the year of publication, subject area, document type, country/territory, languages, source type, types of research and the research methods. It was found that the publications related to FLM in education had dramatically increased from the year 2011 to 2020. The findings of this study also highlighted the importance of FLM in education, especially in courses that require cognitive skills like social studies, medicine, and computer science.
\end{abstract}

Keywords: flipped classroom; content analysis; traditional classroom; Scopus; education.

\section{Introduction}

In the contemporary age of technology and due to the vast availability of computers and gadgets in almost every home, there arises a debate of whether or not the advanced circumstances of today's age make a difference in how students are taught. Is it rational in the present age to have lecturers be just a source of knowledge transfer, in which students perceive it passively? Today, many educators are convinced that a modern school is necessary to create new and completely different educational conditions (Rosario, 2005; Olena, 2013). Possible conditions in education include the introduction of media, personalized learning, the use of various electronic educational resources, such as relevant 
videos, computer-based games, and the implementation of Web 2.0 tools in education (Bicen \& Uzunboylu, 2013). In addition to this, Al-Zahrani asserted that these conditions should serve the purpose of developing critical skills among the learners, planning activities for them and the effective implementation of ideas with the help of technological applications (Al-Zahrani, 2015). In other words, the student should shift from being a passive recipient to an active recipient of knowledge, seeker of truth, discoverer, critical thinker and/or developer (Al-Zahrani, 2015).

The significance of learner corpus research stems from the fact that English is the most widely spoken language on the planet (Seals \& Shah, 2017), as well as the language of science. More specifically, non-native speakers create the vast majority of English spoken around the world (Crystal, 2003). As a result, linguists should focus on the language of non-native speakers and learners, according to NLP and SLA scholars and scientists alike. The results of machine learning show that school practices before, during, and after class have a positive impact on information assimilation and ability growth in database administration. Finally, by engaging students in innovative and active practices, the flipped classroom enhances teaching-learning conditions. This study will be useful to anyone interested in using the flipped classroom teaching approach as an integrated mode of thought and training in the curriculum for long-term multilingualism growth for students.

Knowledge availability has also led to a pronounced change in the role of the educator in the whole process of education. Educators are no longer simply seen as a source of knowledge, but rather as a guide in the world of information, assisting students in critically assessing the reliability and importance of data. In turn, students are now seen as a central figure in the learning process (Andrews, Leonard, Colgrove \& Kalinowski, 2011). In order to meet the modern requirements and to be ready for facing and implementing changes in the learning process, educators must constantly improve their knowledge, following the path of information technology by continuously updating themselves, thus doing their best to carry on with students on virtual roads (Lyu, 2018). 


\section{Literature Review}

Taking into consideration all the aforementioned criteria and conditions, modern educators have developed an educational model called the "Flipped Model". According to the Flipped Learning Network (2014), flipped learning is described as:

[...] a pedagogical approach in which the direct instruction is shifted from group learning space to individual learning space, which as a result, transforms the group learning space into a dynamic and interactive learning environment in which the teacher guides the students while they apply the concepts and get creatively involved in the subject (p. 1).

The definition, shedding light on the concept of flipped learning and its implications in the classroom setting, where the learning patterns turn 'upside down' in terms of lectures and homework indicates, that in contrast to a traditional classroom, the student in a flipped classroom views the lectures at home before coming to the class; thus, as a result the class time is devoted to practical work, learning activities, projects, and discussions. Consequently, this flipped or 'upside down' mode of learning also brings a noticeably significant change in Bloom's taxonomy, the famous hierarchical model for the classification of learning objectives, by altering the upper and lower cognition stages (see Figure 1).

Chuang and Chen (2018) defined the flipped model as an effective learning strategy that helps students' understanding of the concept of the content to be taught in the classrooms beforehand, simply by watching the already prepared video recordings. Most often, an online lecture holds the pivotal position in this learning approach, which integrates several technological tools to make the teaching-learning process in the classroom much easier (Demirel, 2016).

The essence of the FLM is that students get acquainted with lecture materials and presentations at home, watching thematic videos prepared by the lecturers on the Internet, web-based platforms where lecturers share and upload their materials (Zainuddin et al., 2019). In addition, they perform the traditional homework the next day in the classroom participating in 
individual and group activities, communicating with classmates and the lecturer (Cho, Ro \& Littenberg-Tobias, 2013). The characteristics of FLM compared to a traditional classroom are summarized in Table 1 (Naing et al., 2019).

\section{Table 1}

Comparison between Flipped and Traditional Classes

\begin{tabular}{lcc}
\hline Description & Flipped Classroom & Traditional Classroom \\
\hline Teacher centered & - & $\sqrt{ }$ \\
Student centered & $\sqrt{ }$ & - \\
Passive learning environment & - & $\sqrt{ }$ \\
Active learning environment & $\sqrt{ }$ & $\sqrt{ }$ \\
Face-to-face lecture & - & $\sqrt{ }$ \\
First phase (Lecture) & At home & In the classroom \\
Second phase & In the classroom & At home \\
\hline
\end{tabular}

Simply put, the main learning activities are reversed: what used to be done as class work is now perfected at home, and what used to be done at home becomes the subject of consideration in the classroom, where the lecturer guides and facilitates the students and promotes a cognitive critical thinking (Bergman \& Sam, 2012). Among the popular forms of classroom learning in this approach are exercises, discussions, and presentations of the project assigned by teachers. Thus, in the lesson, the emphasis shifts from a review acquaintance with a new subject towards its joint study and research. Moreover, while watching prepared videos, the questions that arise in the minds of students become a good incentive for the development of their cognitive activity. Bergmann and Sams (2012) suggested that teachers keep the videos short and should include various colorful scenes that could work as an intelligent tactic to catch students' attention. This is in line with other researchers who suggested that the videos should be short and should include informal content, believing that it will help to keep students engaged (Kim et al., 2014). The video lectures delivered to the students via such platforms were 
found to be quite beneficial as letting the students watch the content before the class clearly helps them to understand the concepts better and this methodology allows them to maintain their own pace by replaying the videos as many times as they wish.

Furthermore, the learning time is not spent on memorizing the materials, but is spent on a building a deeper understanding and analysis (Rui et al., 2017). Moreover, the absence of the need to convey information to the whole class allows the teacher to pay more attention to individual students or small groups in the cases where they have problems with understanding the material (Sever et al., 2019).

\section{Figure 1}

A Comparison between Flipped and Traditional Lecture according to Bloom's Taxonomy

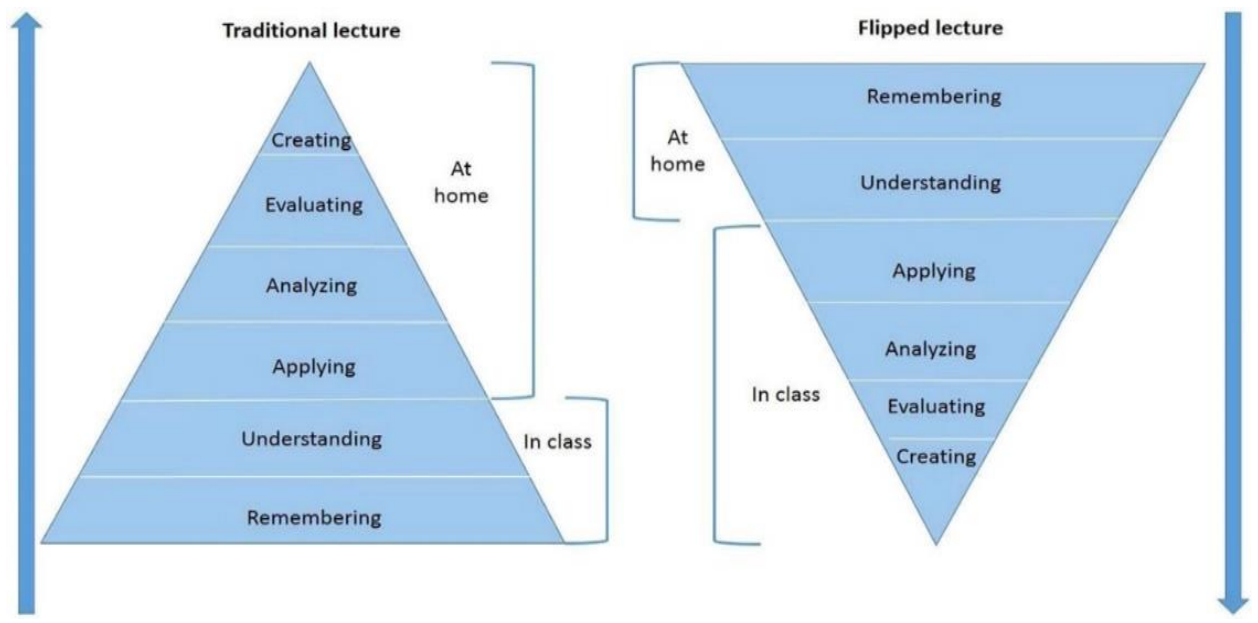

Bormann (2014) conducted a literature review to explore "the effectiveness of a flipped classroom model on student engagement and achievement as well as the affordances of a flipped model vs. a traditional model" by analyzing more than 30 articles on the flipped learning model (p. III). He, with the help of EBSCO database, accessed the articles within the range of five years (20122014) and the study revealed that FLM engaged the students effectively and it 
led them to be better prepared for the 21st century learning and workenvironments" (Bormann, 2014, p. III). The study also concluded that in comparison to its disadvantages, the flipped learning model has more advantages and benefits. Bormann (2014) found out that this model made students quite comfortable and positive while having access to the information and the learners tended to be confident in their learning outside the classroom.

\section{Implications of Flipped Learning Model in English Language Classes}

Using technology in a classroom setting has been found to be a highly effective teaching and learning strategy as it holds the ultimate of having a long lasting impact on the minds of the learners. In regard to the language classroom, (Seljan et al., 2006), have mentioned that the use of technology has brought beneficial and learning-enriched opportunities for language teachers to boost the efficacy of their lessons.

Harstell and Yuen (2006), and Shephard (2003), suggested videos to be a functionally fruitful teaching tool among the technology aids to be used by the teachers across the globe has brought language teachers and instructions. Delivering the teaching content to the learners via videos is one medium to support learning, and this mode of learning is known as flipped learning (Harstell \& Yuen, 2006; Shephard, 2003).

Turan and Cimen (2020) wrote that flipped learning model in ELT context, became popular among the researchers after the year 2014 and there came a noticeable increase in the number of researches carried in the relevant field in the two consecutive years, 2016 and 2017.

Nicolosi (2012) proposed that, by filming videos and adding interactive features to them, ELT teachers using the flipped learning technique in their classrooms would make their lessons more impactful. Moreover, they can use the parts of videos recorded by other teachers in their videos.

According to Basal (2015), while working on listening skills, ELT teachers can benefit from the implementation of the flipped learning model in their classrooms, by exposing the learners to videos where they can get the opportunity to listen to the foreign English speaker. Language learners can 
learn the language essentials like accent, pronunciation and intonation quite well from the direct exposure to native speakers and that is practically possible by listening to them through videos. Bergmann and Sams (2012), describe a flipped classroom as a learning environment where the traditional learning mode gets flipped or inverted that is, what is traditionally taught and learnt in the classroom will now be experienced at home and, on the other hand, which is traditionally done at home as the homework, will supposed to be done in the class. This concept of Bergmann and Sams can be extended to English language teaching because language learning requires practice through discussions and activities, so flipping the conventional teacher-centered classroom to one that focuses on after-discussions is beneficial to language learning.

Basal (2015), keeping in mind the same ambiance as English language instruction, sheds light on the environment of a flipped classroom, where he points out that such classrooms are helpful in that they involve the learners in various hands-on learning activities and subject them to discussions about the relevant ideas, thus making difficult concepts easy and relatable to be understood and remembered, and these methodologies are worth practicing for the language learning process. Basal (2015), further stated that the flipped learning model is a customary term used for the learning setup, which takes into account the involvement of videos in the lessons which are recorded beforehand and he says the whole charm lies in the efficacy of imply those prerecorded videos in the class.

Although the flipped learning paradigm is synonymous with education in general, Anthony Ash believes it has a direct application in ELT classrooms. In a general teaching environment, where the instructor will give lectures on a particular subject in the class, Ash explained that a language teacher will instill the elements, skills, and rules of language in the learners by demonstrating them. Therefore, according to Ash, this text is the main source of knowledge, which the learners use as a reading material outside the classroom or while at home to be prepared beforehand for the upcoming class. Another point, which arises out of this suggestion according to Ash is where these texts and videos can be best stored and in what way the learners can get access to the stored material. In this regard, Anthony Ash spotlighted 
on the practice which some schools follow and indicated that certain schools are running their own LMS (Learning Management System), like Blackboard, which can be best used for storing the content, but apart from this one option, other options have also been suggested by him, which include,

1. Google Drive,

2. Dropbox and

3. YouTube.

Sakulprasertsri and Vibulphol (2017), regarded the flipped learning model to be one of the innovative sources to escalate students' level of motivation and also their class participation or interaction. Basal (2015), concludes that the ELT teachers, once getting familiar and adjusted with the flipped learning model in context to their language teaching process, will find themselves at ease of modifying the teaching styles according to the suitability of learners' learning styles and capacities which he terms as customization of the model.

Such teaching styles, where students feel prompted to discuss their thoughts in groups with their peers also inspire intrinsic motivation, and such a motivation is significant for language learning. Brown (2007) and Dörnyei (2014), advocated that in the whole process of language learning, the factor that stands out to be the most effective and important is motivation, the psychologically proven source of energizing the learner's behavior to strive for achieving the target.

\section{Core Issues in Flipping English Language Classes}

In regard to flipping the ELT classrooms, (Motteram, 2014), indicated that for the implementation of technology in English language classes, one aspect that is very important in this context is the proper training for the concerned teachers. While taking into account the connection of language classroom and technology, Arnold and (Ducate, 2015), highlighted three of the major issues with reference to technology and language instructors. These issues are,

1. The effects of different technological perspectives on the phenomenon of language teaching along with the specific type of 
technology that is used and the extent to which it is used.

2. The continuous progress in learning that is necessary to apply to teaching and the impact of previous teaching experiences in relation to technology.

3. The constantly encouraged use of activities among the language educators involves collaboration and self-evaluation.

\section{Practical considerations for implementing Flipped Learning model in ELT classrooms}

For the ELT teachers who desire to introduce flipped learning model in their classes, below enlisted are some ideas presented by Ahmet Basal (2015), which are practical enough to enhance the value of learning:

1. Consider the learning style that suits to your learners.

2. Be skillful in the use and handling of basic technology.

3. Go for complete planning of what you are supposed to do inside the classroom and what you are supposed to handover for outside the class.

4. Select the activities to aid learning, which you think are suitable for the learners from all aspects and have the capability of adding meaning to the entire process of learning.

5. While choosing activities for your lesson, make sure that you are choosing the ones that can involve all learners.

6. For a better phenomenon of learning to occur in your setting, ensure the inclusion of suitably applicable web 2.0 tools.

7. In order to maintain a balance among the learning activities conducted inside and outside of the classroom, make use of a proper LMS (learning management system).

\section{Material Adaptation for Flipped English Classrooms}

ALTAY (2012), advocates that at some occasions in some contexts, EFL classrooms might face certain economic limitations thus in order to overcome the hindrances occurring in the way to learning, the concerned teachers or 
the institutions can make use of the already prepared and used material with few changes or adaptations in them. He clarifies that these materials might be pictures, texts or recorded videos, which with necessary alterations be reused for a new lesson. These adaptations or changes are made for the purpose of making the lesson aligned with the needs of the learners. ALTAY (2012) proposes that for better results and meaningful learning process, the language teachers need to be quite meticulous and adept in adapting the material to reuse in the classroom to meet the needs of their learners.

Lotherington and Jenson (2011), concluded that the incorporation of technology in any English language setup will have extensive implications which demand the teachers to,

1. Revisit their teaching styles;

2. Go through their major skills;

3. Do their best to cope with the emerging literacy trends;

4. Revise the modes of assessment (Gruba, 2014).

The purpose of this study was to analyze the articles, accessed through a search made on the SCOPUS database with key words "Flipped Classroom in Education" from 2011 to 2020 (21 ${ }^{\text {st }}$ April). The objective of this study was to develop a clear understanding of the Flipped Classroom Model in Education in the last ten years. The sub-objectives, determined to achieve the general aim are as follows:

1. How the documents related to the Flipped Model in Education are distributed over the years?

2. How the documents related to the Flipped Model in Education are distributed according to the subject area?

3. How the documents related to the Flipped Model in Education are distributed according to document type?

4. How the documents related to the Flipped Model in Education are distributed according to country/territory?

5. How the documents related to the Flipped Model in Education are distributed according to languages?

6. How the documents related to the Flipped Model in Education 
are distributed according to source type?

7. Which data collection tools have been used in the studies?

8. Which research models have been used in the studies?

\section{Methodology}

\section{Research Design and Procedure}

This research paper is a study based on a content analysis, the purpose of which is to evaluate and determine the trend of the FLM in the field of Education. Holsti (1969) defines content analysis as, "any technique for making inferences by identifying specified characteristics of messages objectively and systematically" (p. 14). Briefly, content analysis is the technique that compresses large amounts of data, gathered by a researcher, into fewer content categories based on rules of coding (Berelson, 1952).

\section{Figure 2}

The Documents Accessed on the SCOPUS Database through Keywords "Flipped Classroom in Education"

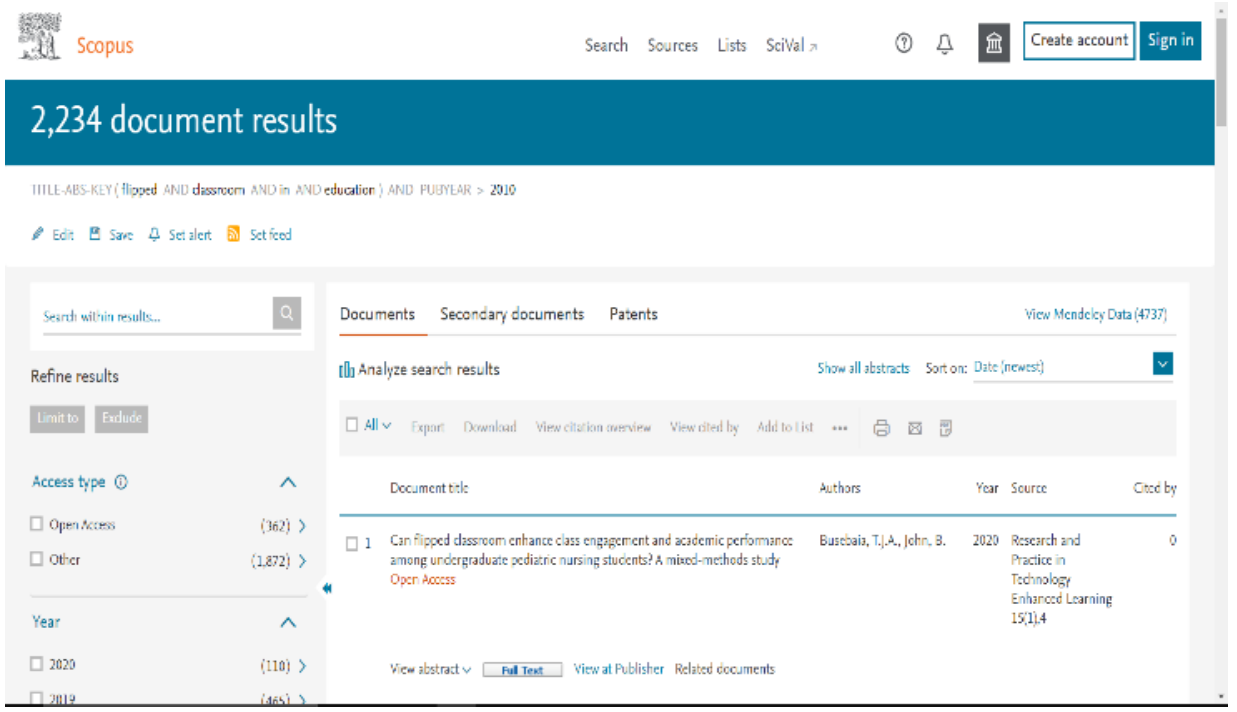


Scopus database has been selected for this study since it was found to be yielding the highest number of documents and the time frame set for collecting the published documents was limited to last ten years between 2011-2020 (21 $1^{\text {st }}$ April). The documents were accessed through the Near East University Scopus database using Near East Grand Library's credentials and the content analysis was limited to only aforementioned eight sub-objectives. FLM was believed to be an innovative and contemporary model that has just recently been implemented into classes. The year 2020 only contains the articles distributed until April 21: the date on which data was collected. In the process of scanning, the keyword entered in the search engine was, "Flipped Classroom in Education". The total number of documents yielded in the whole process of searching was 2.234, however, in this study only 362 Open Access documents were analyzed (Figure 2) as only these were found to be downloaded.

\section{Theoretical/Conceptual Framework}

Despite the growing popularity of flipped learning, neither the concept nor the methodologies used to achieve it have been thoroughly examined in the current body of study, and also have the theoretical underpinnings that could clarify and justify the approach's perceived success. The aim of this paper is to fill a gap in the literature by demonstrating how learning theories relate to the idea of flipped learning and how components of these theories are operationalized.

\section{Data Collection and Analysis}

This study with reference to the mentioned years includes all the documents containing "Flipped Classroom in Education" as a keyword on Scopus. The data collected for this content analysis followed the below-mentioned criteria, narrowed down specifically, in order to gather it in-depth:

\footnotetext{
- Publication Year,

- Subject Area,

- Document Type,

- $\quad$ Research Countries/Territory and Languages,
} 
- Source Type,

- Types of Research,

- $\quad$ Research Methods.

To find the required articles on Flipped Classroom in Education, the Scopus database was utilized where the articles were searched on Scopus database searching engine using the keywords "Flipped Classroom in Education" between the years 2011 and 2020 (21 ${ }^{\text {st }}$ April). As mentioned earlier, the choice of Scopus database over other databases was made due to the availability of increased number of open access documents. The documents retrieved through the Scopus database were put to an investigation according to the abovementioned criteria, and the data was then analyzed using descriptive statistics, simply put, percentages and frequencies. Subsequently, the data was analyzed with the help of the IBM SPSS Statistics package 26 and a Microsoft Excel document was prepared according to stated criteria.

\section{Findings and Discussion}

This research paper was carried out as a content analysis that was initiated with the search on the Scopus database with the keywords 'Flipped Classroom in Education'; eight sub-objectives were narrowed down and a total number of 362 open access documents were analyzed.

\section{Years}

The research revolves around an examination of 362 Open Access documents accessed through the Scopus database between the years 2011 to 2020 (April 21) and their distribution is presented in Figure 3.

Figure 3 demonstrates the distribution of 362 articles obtained from the analysis of the years 2011 to 2020 ( $21^{\text {st }}$ April). It can be seen in Figure 3 that the highest research distribution on the FCM in education occurred in the year $2019(f=116)$ while the lowest occurrence was in $2013(f=2)$. Though the part of research conducted in the year 2020 was limited until April 21, the distribution of articles in the year 2020 also presented notable results yet it is evident from the findings in Figure 3 that, the distribution of articles on 
Flipped Classroom in Education kept on increasing after 21st of April during the year 2020. Interestingly, it was seen that from the year 2013 to 2020 ( $21^{\text {st }}$ April) the distribution of documents has increased in a noticeable way, which shows the increasing popularity of the educational phenomenon, FLM, among scholars, teachers, and students. The findings are in line with Al-Shabibi and Al-Ayasra (2019) who claimed that the number of studies on flipped classroom strategy has been an increased over the years. Lundin et al. (2018) also notified the "substantial increase in the number of academic publications concerned with flipped classroom" (p. 8).

\section{Figure 3}

Number of Articles According to Publication Years

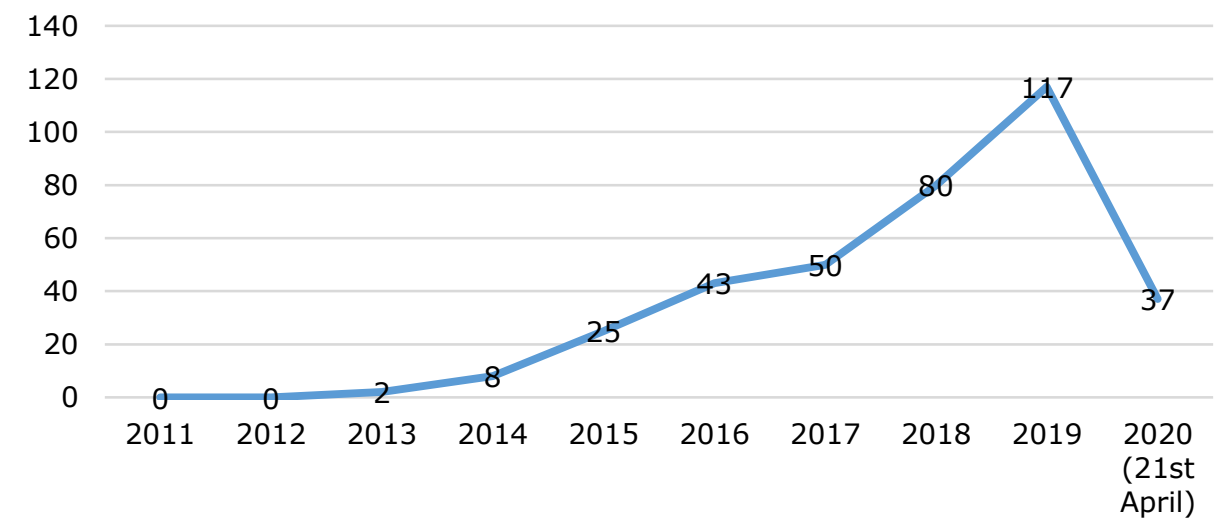

\section{Document Type}

Considering the number of studies in terms of the type of document (see Table 2) it was revealed that the studies on Flipped Classroom in Education were mainly articles $(f=283, \%=78.19)$, followed by conference papers $(f=48$, $\%=13.25)$, reviews $(f=21, \%=5.80)$, erratum $(f=3, \%=0.83)$, note $(f=3$, $\%=0.83)$, book chapter $(f=1, \%=0.27)$, editorial $(f=1, \%=0.27)$, letter $(f=1$, $\%=0.27)$ and retracted $(\mathrm{f}=1, \%=0.27)$. From the above-mentioned revelations, the number of articles seems to be higher because FLM is still in 
its rudimentary form and not generally accepted thus, it is in its research stage. Similarly, the study of Yang et al. (2017) reported that published articles related to FCM were "97.32\%" (p. 179).

\section{Table 2}

Document Type during 2011-2020

\begin{tabular}{lcc}
\hline Document Type & Frequency & \% \\
\hline Article & 283 & 78.19 \\
Conference Paper & 48 & 13.25 \\
Review & 21 & 5.80 \\
Erratum & 3 & 0.83 \\
Note & 3 & 0.83 \\
Book Chapter & 1 & 0.27 \\
Editorial & 1 & 0.27 \\
Letter & 1 & 0.27 \\
Retracted & 1 & 0.27 \\
\hline Total & $\mathbf{3 6 2}$ & $\mathbf{1 0 0}$ \\
\hline
\end{tabular}

\section{Countries/Territory}

When the distributed studies on Flipped Classroom in Education, considered on the basis of countries between the years of 2011 to 2020 (21st April), were analyzed, it was found that the majority of documents were produced in the North American; USA ( $f=201, \%=55.52$ ) (see Table 3 ). These findings were also revealed in the study of Al-Shabibi and Al-Ayasra (2019) that linked the higher number of studies on this topic with the regions of the U.S.A, where this strategy originated (p. 104). In addition, Lundin et al. (2018) found out that as per geography, the research on the flipped classroom seems dominated by publications from the United States (p. 8). Following the USA, China ( $f=37$, $\%=10.22)$ was seen as the second, Spain $(f=35, \%=9.66)$ third, Indonesia $(f=20, \%=5.52)$, Russian Federation $(f=16, \%=4.44)$, followed by Australia, 
Canada and the Netherlands $(\mathrm{f}=11$ and $\%=3.04)$ respectively. The least number of articles on Flipped Classroom in Education were seen in Malaysia and Taiwan $(f=10, \%=2.76)$. From the data retrieved, we conclude that the countries utilizing FLM the most include the United States, Europe and Asia.

\section{Table 3}

Countries/Territory during 2011-2020

\begin{tabular}{lcc}
\hline Country/Territory & Frequency & \% \\
\hline Unites States & 201 & 55.52 \\
China & 37 & 10.22 \\
Spain & 35 & 9.66 \\
Indonesia & 20 & 5.52 \\
Russian Federation & 16 & 4.44 \\
Australia & 11 & 3.04 \\
Canada & 11 & 3.04 \\
Netherlands & 11 & 3.04 \\
Malaysia & 10 & 2.76 \\
Taiwan & 10 & 2.76 \\
\hline Total & $\mathbf{3 6 2}$ & $\mathbf{1 0 0}$ \\
\hline
\end{tabular}

\section{Languages}

When the documents on Flipped Classroom in Education between the years 2011 to 2020 ( $21^{\text {st }}$ April) were analyzed in regard to language, it was found out that 331 articles $(\%=91.43)$ were written and distributed in the English Language, making it dominant in the studies on 'Flipped Classroom in Education' (see Table 4). This finding ascertains the fact that English is the most widely spoken language worldwide (Seals \& Shah, 2017, as cited in Almohizea, 2017). Spanish Language $(f=18, \%=4.97)$ was seen as the secondhighest language. Furthermore, there were few other studies written in other languages: Russian $(f=4, \%=1.10)$, Portuguese $(f=3, \%=0.83)$ and Turkish 
$(\mathrm{f}=3, \%=0.83)$. The least number of studies on Flipped Classroom in Education were written in French $(f=1, \%=0.28)$, German $(f=1, \%=0.28)$ and Japanese $(\mathrm{f}=1, \%=0.28)$. It is evident that English and Spanish are the dominant languages in the respective area of research because of the wide acceptance and effective utility of FLM in the North American and European countries.

\section{Table 4}

Languages during 2011-2015

\begin{tabular}{lll}
\hline Languages & Frequency & \% \\
\hline English & 331 & 91.43 \\
Spanish & 18 & 4.97 \\
Russian & 4 & 1.10 \\
Portuguese & 3 & 0.83 \\
Turkish & 3 & 0.83 \\
French & 1 & 0.28 \\
German & 1 & 0.28 \\
Japanese & 1 & 0.28 \\
\hline Total & $\mathbf{3 6 2}$ & $\mathbf{1 0 0}$ \\
\hline
\end{tabular}

\section{Subject Area}

When the documents on Flipped Classroom in Education were analyzed under the subject area (see Table 5), it was seen that the relevant researches mainly focused on Social Studies $(f=151, \%=41.71)$ along with Computer Science ( $f=56, \%=15.47)$ and the least studies were seen in the areas of Arts and Humanities and Business Management and Accounting ( $f=8, \%=2.21$ ).

Based on the findings, it is stated that the implementation of FCM in the content-based subjects requiring cognitive skills (social studies, computer science, medicine and so on) is more effective rather than subjects involving arithmetic and logical skills (Management and Accounting, Mathematics, Engineering). This is in line with the study of Al-Shabibi and Al-Ayasra (2019) 
who found that FCM has lesser or limited implications in "applied science such as mathematics and science" (p. 105). Erdogan and Akbaba (2018) conducted a study regarding flipped classroom the aim of which was to explore the opinions of teachers on flipped classroom in Social Studies, and their phenomenological study, laid out the fact that integrating FLM into Social Sciences solves problems like time management and absences (Erdogan \& Akbaba, 2019).

\section{Table 5}

Subject Areas during 2011-2020

\begin{tabular}{lcc}
\hline Subject Areas & Frequency & \% \\
\hline Social Sciences & 151 & 41.71 \\
Computer Science & 56 & 15.47 \\
Medicine & 37 & 10.22 \\
Engineering & 36 & 9.95 \\
Biochemistry, Genetics, and Molecular Biology & 19 & 5.25 \\
Mathematics & 19 & 5.25 \\
Physics and Astronomy & 16 & 4.42 \\
Psychology & 12 & 3.31 \\
Arts and Humanities & 8 & 2.21 \\
Business, Management and Accounting & 8 & 2.21 \\
\hline Total & $\mathbf{3 6 2}$ & $\mathbf{1 0 0}$ \\
\hline
\end{tabular}

\section{Source Type}

When the studies on Flipped Classroom in Education were analyzed according to the source type (see Table 6), it was revealed that the studies were mainly published in journals $(f=311, \%=85.92)$ and the studies were published as conference proceedings or conference papers $(f=46, \%=12.70)$. The least number of studies was distributed as Book Series $(f=5, \%=1.38)$. Since FLM 
was researched through articles, it is clear that they were mainly published in journals.

\section{Table 6}

Source Types during 2011-2020

\begin{tabular}{lcc}
\hline Source Type & Frequency & \% \\
\hline Journals & 311 & 85.92 \\
Conference Proceedings & 46 & 12.70 \\
Book Series & 5 & 1.38 \\
\hline Total & $\mathbf{3 6 2}$ & $\mathbf{1 0 0}$ \\
\hline
\end{tabular}

\section{Research Design}

The 362 FCM based studies involved different methodologies the analysis of which explored that the documents distributed on FLM in education, within the range of ten years (2011-2020), mostly employed mixed-methods research design $(\mathrm{f}=178, \%=49.17)$, followed by a quantitative research design $(\mathrm{f}=121, \%=33.43)$. The analysis of research design revealed that multiple tools were utilized to collect in-depth information revealing the effectiveness of the FCM (e.g., Bouwmeester et al., 2019; Burns et al., 2019; Finkenberg \& Trefzger, 2019; Halasa et al., 2019; Jitjumnong \& Suksakulchai, 2019; ParraGonzalez et al., 2020; Wang \& Zhu, 2019; Yang et al., 2019; Zamora-Polo et al., 2019). The tools utilized in gathering the required data were mainly surveys, questionnaires, observations, interviews and field notes. For example, Umam et al. (2019) used observations, written journals and tests for the very purpose. Roux and Nagel (2018) conducted a case study adopting a mixedmethod design, using questionnaires, interviews and observations as the main tool.

Another utilized method was a quantitative approach ( $\mathrm{f}=121$, $\%=33.43$ ) and studies using a quantitative research design mainly focused on 
students' perceptions and effectiveness of FCM through surveys (see Table 7).

Table 7

Research Applied

\begin{tabular}{lcc}
\hline Types of research & Frequency & \% \\
\hline Quantitative-Qualitative (Mixed) & 178 & 49.17 \\
Quantitative & 121 & 33.43 \\
Qualitative & 53 & 14.64 \\
Documentary Review & 10 & 2.76 \\
\hline Total & $\mathbf{3 6 2}$ & $\mathbf{1 0 0}$ \\
\hline
\end{tabular}

Quantitative research design has been adopted by many researchers studying FLM (e.g., Battestilli, Dominguez \& Thyagarajan, 2020; Rathner \& Schier, 2020; Rueda, 2020; Sprint \& Fox, 2020; Zante, Hautz \& Schefold, 2020; Zheng \& Zhang, 2020). While integrating an FCM, İsmail and Abdulla (2019) for instance, used one-group pretest-posttest quasi-experimental research design in order to measure the motivational level and learning achievement of the students. In addition, a good number of articles also used a qualitative research design $(f=53, \%=14.64)$ and the studies using a qualitative research design focused on teachers and students' perceptions along with students' academic outcomes thus numbers of studies have been conducted using a qualitative approach. (e.g., Ha et al., 2019; Hernandez-Silva \& Flores, 2017; Musdi et al., 2019; Osterlie \& Kjelaas, 2019; Zheng et al., 2019). Rachmawati et al. (2019) conducted a qualitative research the objective of which was to explore teachers' perception on the practicality of flipped classroom in the subject of mathematics. The data was gathered through an interview using a qualitative approach, the findings of which showed that "flipped classrooms can I inspire and engage students in learning mathematics; (ii) train students in developing critical thinking skills; (iii) train students in problem-solving skills" (Rachmawati et al., 2019, p. 1). 


\section{Research Methods}

Table 8 demonstrates the research methods employed in articles on Flipped Classroom in Education published between 2011-2020 (April 21 ${ }^{\text {st }}$ ) which indicates that quasi-experimental research design $(f=77, \%=34.38)$ was the most preferred design in the studies on flipped classrooms in education, along with experimental design $(f=65, \%=29.01)$ and case studies $(f=48$, $\%=21.43)$.

\section{Table 8}

Researching Methods of Articles

\begin{tabular}{lcc}
\hline Researching Methods & Frequency & \% \\
\hline Quasi-experimental & 77 & 34.38 \\
Experimental design & 65 & 29.01 \\
Case Study & 48 & 21.43 \\
Survey Research & 12 & 5.35 \\
Descriptive & 11 & 4.91 \\
Context Analysis & 4 & 1.79 \\
Meta-Analysis & 4 & 1.79 \\
Scale Development & 3 & 1.34 \\
\hline Total & $\mathbf{2 2 4}$ & $\mathbf{1 0 0}$ \\
\hline
\end{tabular}

Survey research $(f=12, \%=5.35)$ was seen as the fourth most employed research design. After analyzing the documents, only four content analyses of the FCM in education were found among scanned articles. This demonstrates the deficiency and lack of availability of papers based on content analysis on Flipped Classroom in Education.

\section{Conclusions, Recommendations and Limitations}

The educational realm has shifted in terms of continuous introduction of innovative approaches and methodologies most of which involve 
implementation of new technologies. Thus, it has become necessary to apply the emerging innovations in the field of education to cope with the standards of modern era (Mehring, 2016). The shift to the "Flipped Classroom" model undergoes a transition of roles from the leadership of the teacher to the leadership of the student. Unlike the traditional classrooms, the educational process involving flipped classrooms, takes students as the active participants. In addition, the FCM holds a considerably noteworthy significance for EFL students (Moraros et al., 2015). As per the findings of this content analysis, it is evident that the number of publications related to the FCM in education have dramatically increased from the years between 2011 to 2020 ( $21^{\text {st }}$ April) which clearly demonstrates the interest of teachers, students and researchers in the implementation of the respective model (Rachmawati et al., 2019; Erdogan \& Akbaba, 2018). Revealing the importance of Flipped Learning in Education, the findings of this study spotlights the fact that this model has found to be rather more effective in the teaching of subjects that require cognitive skills like social studies, medicine, and computer science, moreover it was found that FLM was mostly practiced in the United States, Europe and Asia. Based on the fact, that FLM is mostly employed in the North American, European and Asian countries, it is evident that the dominant languages in the research are English and Spanish. The findings of this study also reveal that the studies used for the research under question were mainly journals articles and the research design used in researches taken from the articles on FLM in Education was mostly mixed method the reason of which was the requirement of a detailed and in-depth data due to the unclearness of the FLM.

This research paper was kept limited to the selected and reviewed articles in the Scopus searching engine published between 2011 and 2020 ( $21^{\text {st }}$ April). According to the findings, the flipped classroom will provide students with a more engaging learning atmosphere, resulting in higher learning achievement and better training for the $21^{\text {st }}$-century, learning and work environments. This delimitation calls for further analysis on papers comprising of content analysis with a different yet increased number of subobjectives. It would be valuable to carry out another content analysis paper with different databases, such as EBSCO, Google Scholar, Web of Science, Research gate, etc. When there's a lot of talk about how effective the flipped 
classroom is, it's important to know how the concept of flipped learning changes pedagogy. As a result, this literature review aimed to look into the impact of a flipped classroom model on student engagement and achievement, as well as the benefits of a flipped model over a conventional model.

\section{References}

Almohizea, M. I. (2017). The Compilation Process of (COLTLC): A Learner Corpus. International Journal of Language and Linguistics, 4(4), 223231.

Al-Shabibi, T. S., \& Al-Ayasra, M. A. (2019). Effectiveness of the flipped classroom strategy in learning outcomes (bibliometric study). International Journal of Learning, Teaching and Educational Research, 18(3), 96-127.

Altay, I. F. (2012). Adapting materials in English language teaching. Honorary Chairperson. Book of proceedings of the $3^{\text {rd }}$ Black Sea ELT Conference "Technology: A Bridge to Language Learning" November 15-17, 106130.

Al-Zahrani, A. (2015). From passive to active: The impact of the flipped classroom through social learning platforms on higher education students' creative thinking. British Journal of Educational Technology, 46(6), 1133-1148.

Andrews, T. M., Leonard, M. J., Colgrove, C. A., \& Kalinowski, S. T. (2011). Active learning not associated with student learning in a random sample of college biology courses. Life Sciences Education, 10(4), 394405. https://doi.org/10.1187/cbe.11-07-0061

Ash, A. (n.d.). Flipping the Lesson in ELT. International House World Organisation.

Basal, A. (2015). The implementation of a flipped classroom in foreign language teaching. Turkish Online Journal of Distance Education, 16(4), 28-37.

Battestilli, L., Domínguez, I. X., \& Thyagarajan, M. (2020). Toward finding online activity patterns in a flipped programming course. SIGCSE, 1114. 
Berelson, B. (1952). Content analysis in communication research. Glencoe. Bergmann, J., \& Sams, A. (2012a). Before you flip, consider this. New Styles of Instruction, 94(2), 25. https://www.researchgate.net/ publication/262091821_Before_You_Flip_Consider_This

Bergmann, J., \& Sams, A. (2012b). Flip your classroom: Reach every student in every class every day. International Society for Technology in Education.

Bicen, H., \& Uzunboylu, H. (2013). The use of social networking sites in education: A case study of Facebook. Journal of Universal Computer Science, 19(5), 658-671.

Bormann, J. (2014). Affordances of flipped learning and its effects on student engagement and achievement. Graduate Research Papers, 1-34.

Bouwmeester, R. A. M., De Kleijn, R. A. M., Van de Berg, I. E. T., Cate, O. T., Van Rijen, H., \& Westerveld, H. (2019). Flipping the medical classroom: Effect on workload, interactivity, motivation and retention of knowledge. Computer \& Education, 139, 118-128.

Burns, W. P., Hartman, N. D., Weygandt, P. L., Caretta-Weyer, H., \& Moore, K. G. (2019). Critical electrocardiogram curriculum: Setting the standard for flipped-classroom EKG instruction. Western Journal of Emergency Medicine, 21(1), 52-57. https://doi.org/10.5811/westjem.2019.11.44509

Cho, V., Ro, J., \& Littenberg-Tobias, J. (2013). What twitter will and will not do: Theorizing about teachers' online professional communities. Learning Landscapes, 6(2), 45-62.

Chuang, H. H., Weng, C. Y., \& Chen, C. H. (2018). Which students benefit most from a flipped classroom approach to language learning? British Journal of Educational Technology, 49(1), 56-68. https://doi.org/10.1111/bjet.12530.

Demirel, E. E. (2016). Basics and key principles of flipped learning classes upside down. International Journal of Languages, Literature and Linguistics, 2(3),109-112.

Erdogan, E., \& Akbaba, B. (2018). Should we flip the social studies classrooms? The opinions of social studies teacher candidates on flipped classroom. Journal of Education and Learning, 7(1), 116-124. 
Finkenberg, F., \& Trefzger, T. (2019). Flipped classroom in secondary school physics education. Journal of Physics: Conf. Series, 1286. https://doi.org/10.1088/1742-6596/1286/1/012015.

Flipped Learning Network (2014). The four pillars of F-L-I-PTM. http://linpilcare.eu/images/TOOLS/142/142.pdf

Ha, A., O'Relly, J., Ng, J. Y. Y., \& Zhang, J. H. (2019). Evaluating the flipped classroom approach in Asian higher education: Perspectives from students and teachers. Cogent Education, 6(1).

Halasa, S., Abusalim, N., Rayyan, M., Constantino, R. E., Nassar, O., Amre, H., Sharab, M., \& Qadri, I. (2019). Comparing student achievement in traditional learning with a combination of blended and flipped learning. Nursing Open, 7, 1129-1138. https://doi.org/10.1002/nop2.492

Hall, G. (Ed.). (2016). The Routledge handbook of English language teaching. Routledge.

Hernandez-Silva, C., \& Flores, S. T. (2017). Flipped classroom mediated by the use of virtual platforms: A case study of pre-service teacher education in physics. Estudios Pedagógicos, 193-204.

Holsti, O. R. (1969). Content Analysis for the Social Sciences and Humanities. Reading, MA: Addison-Wesley.

Jitjumnong, K., \& Suksakulchai, S. (2019). Comparison study of student's learning achievement between the flip classroom with and without group management. International Journal of Information and Education Technology, 9(12), 904-908.

Kim, M. K., Kim, S. M., Khera, O., \& Getman, J. (2014). The experience of three flipped classrooms in an urban university: An exploration of design principles. The Internet and Higher Education, 22, 37-50. https://doi.org/10.1016/j.ineduc.2014.04.003

Lyu, C. (2018). Study on the innovative development of Korean language teaching in universities in the background of quality education. Advances in Social Science, Education and Humanities Research, 238, 648-651.

Mehring, J. (2016). Present research on the flipped classroom and potential tools for the EFL classroom. Computers in the Schools, 33(1), 1-10. https://doi.org/10.1080/07380569.2016.1139912 
Moraros, J., Islam, A., Yu, S., Banow, R., \& Schindelka, B. (2015). Flipping for success: Evaluating the effectiveness of a novel teaching approach in a graduate level setting. BMC Medical Education, 15(1). https://doi.org/10.1186/s12909-015-0317-2

Musdi, E., Agustyani, A. R. D., \& Tasman, F. (2019). Students' perception toward flipped classroom learning. Journal of Physics: Conf. Series, 1320. https://doi.org/10.1088/1742-6596/1317/1/012132

Nicolosi, A. (2012). Grammar lessons with the flipped classroom method. Honorary Chairperson, 13.

Olena, P. (2013). Problem of legal Education of the future specialists on computer field. Academic Society of Michal Baludansky, 3, 141-144.

Osterlie, O., \& Kjelaas, I. (2019). The perception of adolescents encounters with a flipped learning intervention in Norwegian physical education. Frontiers in Education, 4(114), 1-12.

Parra-Gonzalez, M. E., Belmonte, J. L., Segura-Robles, A., \& Cabrera, A. F. (2020). Active and emerging methodologies for ubiquitous education: potentials of flipped learning and gamification. Sustainability, 12(602), 1-11. https://doi.org/10.3390/su12020602

Rachmawati, V., Setyaningrum, W., \& Retnawati, H. (2019). Flipped classroom in mathematics instruction: Teachers' perception. Journal of Physics: Conf. $\quad$ Series, $1320 . \quad$ https://doi.org/10.1088/17426596/1320/1/012088

Rathner, J. A., \& Schier, M. A. (2020). The impact of flipped classroom andragogy on student assessment performance and perception of learning experience in two advanced physiology subjects. Advances in Physiology Education, 44, 80-92. https://doi.org/10.1152/ advan.00125.2019

Rosario, M. (2005). The Mongolian drop out study. Mongolian Education Alliance. Ulaanbataar, Mongolia.

Rueda, R. A. S. (2020). Use of the flipped classroom to design creative and active activities in the field of Computer science. Creativity Studies, 13(1), 136-151.

Rui, Z., Lian-rui, X., Rong-zheng, Y., Jing, Z., Xue-hong, W., \& Chuan, Z. (2017). Friend or foe? Flipped classroom for undergraduate 
electrocardiogram learning: A randomized controlled study. BMC Medical Education, 17(1), 53. https://doi.org/10.1186/s12909-0170881-8

Sakulprasertsri, K. (2014). Effects of an English instruction using the flipped learning approach on English oral communication ability and motivation in English learning of upper secondary school students [Unpublished doctoral dissertation]. Chulalongkorn University.

Seals, C. A., \& Shah, S. (Eds). (2017). Heritage language policies around the world. Routledge.

Sever, I., Öncül, B., \& Ersoy, A. (2019). Using flipped learning to improve scientific research skills of teacher candidates. Universal Journal of Educational Research, 7(2), 521-535.

Sprint, G., \& Fox, E. (2020). Improving student study choices in CS1 with gamification and flipped classrooms. SIGCSE, 11-14.

Turan, Z., \& Akdag-Cimen, B. (2020). Flipped classroom in English language teaching: A systematic review. Computer Assisted Language Learning, 33(5-6), 590-606.

Wang, K., \& Zhu, C. (2019). MOOC-based flipped learning in higher education: Students' participation, experience and learning performance. International Journal of Educational Technology in Higher Education, 16(33), 2-18.

Yang, L., Sun, T., \& Liu, Y. (2017). A bibliometric investigation of flipped classroom research during 2000-2015. International Journal of Engineering \& Technology, 12(6), 178-186.

Yang, S., Liu, Y., \& Todd, A. G. (2019). Effects of flipped classroom on highand low-achievers' English vocabulary learning. The Journal of Asia TEFL, 16(4), 1251-1267.

Zainuddin, Z., Habiburrahim, H., Muluk, S., \& Keumala, C. M. (2019). How do students become self-directed learners in the EFL flipped-class pedagogy? A study in higher education. Indonesian Journal of Applied Linguistics, 8(3), 678-690.

Zamora-Polo, F., Corrales-Serrano, M., Sánchez-Martín, J., \& EspejoAntúnez, L. (2019). Nonscientific university students training in general science using an active-learning merged pedagogy: 
Gamification in a flipped classroom. Education Sciences, 9(297), 2-18. http://dx.doi.org/10.3390/educsci9040297

Zante, B., Hautz, W. E., \& Schefold, J. C. (2020). Physiology education for intensive care medicine residents: A 15-minute interactive peer-led flipped classroom session. Plos One, 15(1).

Zheng, B., \& Zhang, Y. (2020). Self-regulated learning: The effect on medical student learning outcomes in a flipped classroom environment. BMC Medical Education, 20(100), 1-7. https://doi.org/10.1186/s12909020-02023-6 


\section{Rustam Haidov}

Artimuju Rytu universitetas, Kipras; rustamhaidov@hotmail.com Hanife Bensen

Artimuju Rytu universitetas, Kipras; hanife.bensen@neu.edu.tr

\section{ATVIRKŠTINIS MOKYMASIS UGDYMO SRITYJE: TURINIO ANALIZÉ}

Santrauka. Nuolat tobulejanti XXI a. švietimo sistema reikalauja diegti inovatyvias mokymo metodikas, apimančias i naujausias technologijas nukreiptus metodus, galinčius vietoje tradiciniu pamoku vedimo būdu, kuriems būdinga, kad mokytojas yra svarbiausias žiniu šaltinis, perteikti nauja samprata, pagal kuria mokytojas laikomas pagalbininku ir vedliu informacijos pasaulyje. Atlikta daugybe tyrimu, susijusiu su atvirkštiniu mokymusi, tačiau moksliniu straipsniu, kuriuose pateikiama turinio analizė, negausu, - tai rodo, kad trūksta turinio analize pagristu darbu apie atvirkštinę klasę ugdymo procese. Taigi, norint užpildyti šią spraga, būtina atlikti turinio analizę. Savo ruožtu šio straipsnio tikslas buvo nustatyti platinamy dokumentu svarbą ir itaką atvirkštinio mokymosi modeliui (angl. Flipped Learning Model, FLM) ugdymo srityje. Tyrimas buvo atliktas renkant duomenis iš duomenu bazès SCOPUS su reikšminiais žodžiais "Flipped Classroom in Education" (atvirkštinè klasė ugdymo srityje) dešimties metu laikotarpiu (2011-2020 m.). Visi SCOPUS sistemoje paskelbti moksliniai tyrimai buvo statistiškai analizuojami ir nagrinejami pagal publikavimo metus, teminę sriti, dokumento tipa, šali (teritorija), kalbas, ištekliu tipa, tyrimu pobūdi ir tyrimo metodus. Nustatyta, kad nuo 2011 iki 2020 m. labai padaugejo publikaciju, susijusiu su FLM ugdymo srityje. Šio tyrimo rezultatai taip pat pabrěžè FLM svarba ugdymo srityje, ypač mokant tu dalyku, kuriems perprasti reikalingi kognityviniai igūdžiai, pavyzdžiui, socialiniu mokslu, medicinos ir informatikos srityse.

Pagrindinès sąvokos: atvirkštinè klasè; turinio analizè; tradicinè klasè; SCOPUS; ugdymas. 